\title{
EMERGENCE SUPPRESSION OF BARK AND AMBROSIA BEETLES IN INFESTED OAKS
}

\author{
By Pavel Švihra', Deborah F. Crosby ${ }^{2}$, and Becky Duckles ${ }^{3}$
}

\begin{abstract}
Logs were cut from each of eight coast live oaks (Quercus agrifolia) and one California black oak (Q. kelloggii) infested with bark and ambrosia beetles. For each tree, one log was collected from $1 \mathrm{~m}(3.3 \mathrm{ft})$ above the ground, a second from immediately below the crotch of the major limbs, and a third from a branch $8 \mathrm{~cm}$ (3 in.) in diameter. Permethrin significantly reduced emergence of both oak ambrosia beetles (Monothrum scutellare) and oak bark beetles (Pseudopityphthorus pubipennis) from the insecticide-treated $\operatorname{logs}(\mathrm{P}=0.001)$ compared to the control log sections. This result indicates the bark application of permethrin can lower the density of bark and ambrosia beetles in urban forests.

Key Words. Pseudopityphthorus pubipennis; Monothrum scutellare; Quercus; permethrin; emergence; prevention; plant health; Phytophthora.
\end{abstract}

attacks are associated with (1) hastening both oak decline and death and (2) ambrosia beetle galleries penetrating deep to the sapwood and inducing breakage of the stems of infested coast live oaks. Ambrosia beetle tunneling into the sapwood has been reported to be associated with tree failure in beeches affected by beech bark disease in Europe (Speight 1981). This new phenomenon in the coastal oak woodlands has profound implications, since stems of many trees break even while trees display green foliage (Figure1) Infections by $P$. ramorum combined with beetle population outbreaks not only affect the dynamics of oak woodlands and urban forest management but may also become dangerous in situations where subsequently infested coast live oaks display seemingly healthy foliage but become a hazard when they unpredictably snap.

The western oak bark beetle (Pseudopityphthorus pubipennis) and the oak ambrosia beetles (Monothrum scutellare and M. dentiger) (all Coleoptera: Scolytidae) are native to California and other parts of the western United States. In California, they occur wherever their hosts, including oaks and tanoak, are found. Interest in these beetle species has increased recently due to their close association with trees infected by Phytophthora ramorum, the pathogen that causes sudden oak death (Rizzo et al. 2002). The biology of these species has been described by Bright and Stark (1973) and Furniss and Carolin (1978). All three species were reported to attack stressed, dying, and recently dead trees and were described as economically unimportant secondary species. Recently, epidemic populations of these insects have been implicated as a cause of mortality of coast live oak (Quercus agrifolia) and California black oak (Q. kelloggii) in coastal forests of California (Švihra 2000). Their populations rose to epidemic levels after the causal pathogen of sudden oak death (P. ramorum) emerged in 1995 (Garbelotto et al. 2000; Rizzo et al. 2002).

The first symptom of infection by the sudden oak death pathogen is bleeding or seeping on the surface of the main stem. Soon after this symptom becomes visible on the bark surface, oak bark beetles and oak ambrosia beetles aggregate and attack the tree close to the bleeding sites. These

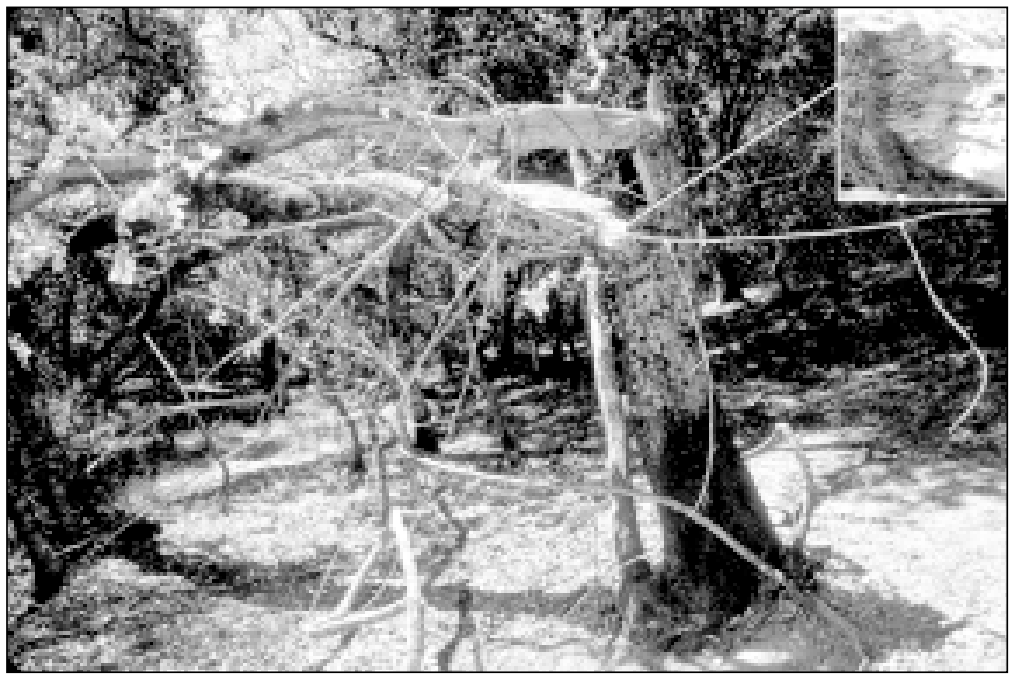

Figure 1. This coast live oak displayed healthy green foliage when it snapped in June 2001 after heavy rain. Examination of the broken stem revealed heavy infestation of ambrosia beetles (insert) at the breakage point.

Bark and ambrosia beetle suppression may be critical to (1) increasing survival time of trees infected with P. ramorum and (2) preventing the breakage of coast live oaks with green canopies in California. Studies are under way to determine the effects of insecticides on tree survival. In this paper, we report on the efficacy of Astro [permethrin; 
chemical name cyclopropanecarboxylic acid, 3-(2,2dichloroethenyl)2,2-dimethyl-(3-phenoxyphenyl) methyl ester] in reducing emergence of $P$. pubipennis and $M$. scutellare. If successful, this method could be effective in suppressing beetle populations on a local scale, thereby reducing the chances of uninfested trees becoming infested. A number of studies have been conducted to test effectiveness of chemical insecticides (lindane, chlorpyrifos, carbaryl, metasystox, fenitrothion) for protecting single conifers in urban areas (Brady et al. 1980; Hall et al. 1982).

The P. pubipennis female constructs an approximately $5 \mathrm{~cm}$ (2 in.) long, two-branched transverse egg gallery between the bark and wood, extending tunnels in either direction from the entrance hole and often engraving the wood (Figure 2A). The hatched larvae mine upward and downward with the grain into the inner bark. Pupation occurs just beneath the surface of the bark where newly formed adults make their own exit holes, emerge, and fly to attack other oaks.

The M. scutellare male penetrates the sapwood to a depth of $5 \mathrm{~cm}$ ( $2 \mathrm{in}$.). The female joins the male, mates, and introduces the ambrosia fungus (Monilia brunnea). Both sexes excavate two to four diverging galleries deep into the sapwood-heartwood area, each 5 to $15 \mathrm{~cm}$ (2 to 6 in.) long (Figure 2B). The female excavates egg niches in the sidewalls of the galleries. The hatched larvae extend the egg niches into "larval cradles." The ambrosia fungus grows into the cradles and serves as a larval food source for the beetles. After 3 to 4 months, new adult beetles emerge through the same entrance holes made by parent beetles. The biology of M. dentiger is similar.

The objective of this study was to demonstrate the effectiveness of surface treatments of logs as a method for reducing emergence of bark and ambrosia beetles.

\section{MATERIALS AND METHODS}

Between June 14 and 17, 2000, in Marin County, California, U.S., three $40 \mathrm{~cm}$ (16 in.) long bolts were removed from each of eight heavily infested coast live oaks (Q. agrifolia) and one black oak (Q. kelloggii) in the following sequence: the first bolt, $1 \mathrm{~m}$ (3.3 ft) above the ground; the second, under the crotch of the major limbs; and the third, from one branch $8 \mathrm{~cm}$ (3 in.) in diameter. Each bolt was then cut vertically into two halves. One half from each bolt was selected at random and its bark surface sprayed with the insecticide Astro (permethrin), while the other half (control) was not sprayed. On June 17, 2000 , the tested insecticide was applied at the label rate of $0.5 \%$. Bolt halves to be treated were placed with the cut area on the ground, and each bark surface was sprayed to the point of runoff using a hand sprayer. Bolt halves were placed into separate rearing containers that comprised a plastic garbage can covered tightly with a lid into which a fan had been inserted to provide air circulation. On the bottom side of each can, a circular hole was cut to exactly fit a collecting jar. A clear glass mason jar filled with moist paper was screwed tightly into each hole. Emerging beetles followed the light and dropped into the jars. The cans were shaded with plastic roofing panels and held at ambient temperatures that ranged between $16^{\circ} \mathrm{C}$ and $27^{\circ} \mathrm{C}\left(60^{\circ} \mathrm{F}\right.$ and $\left.81^{\circ} \mathrm{F}\right)$. Insects emerging into the collection jars were collected daily between 9:00 A.M. and 10:00 A.M., sorted by species, and counted. To suppress fungal growth on dead beetles inside the rearing containers, the bolts were removed every $48 \mathrm{~h}$, and dead beetles were collected, identified, and counted. The walls and bottom of each rearing container were washed with detergent and dried with paper towels, and the bolts were placed back inside to continue the rearing process. Beetle collection continued until emergence had ceased on December 9, 2000.

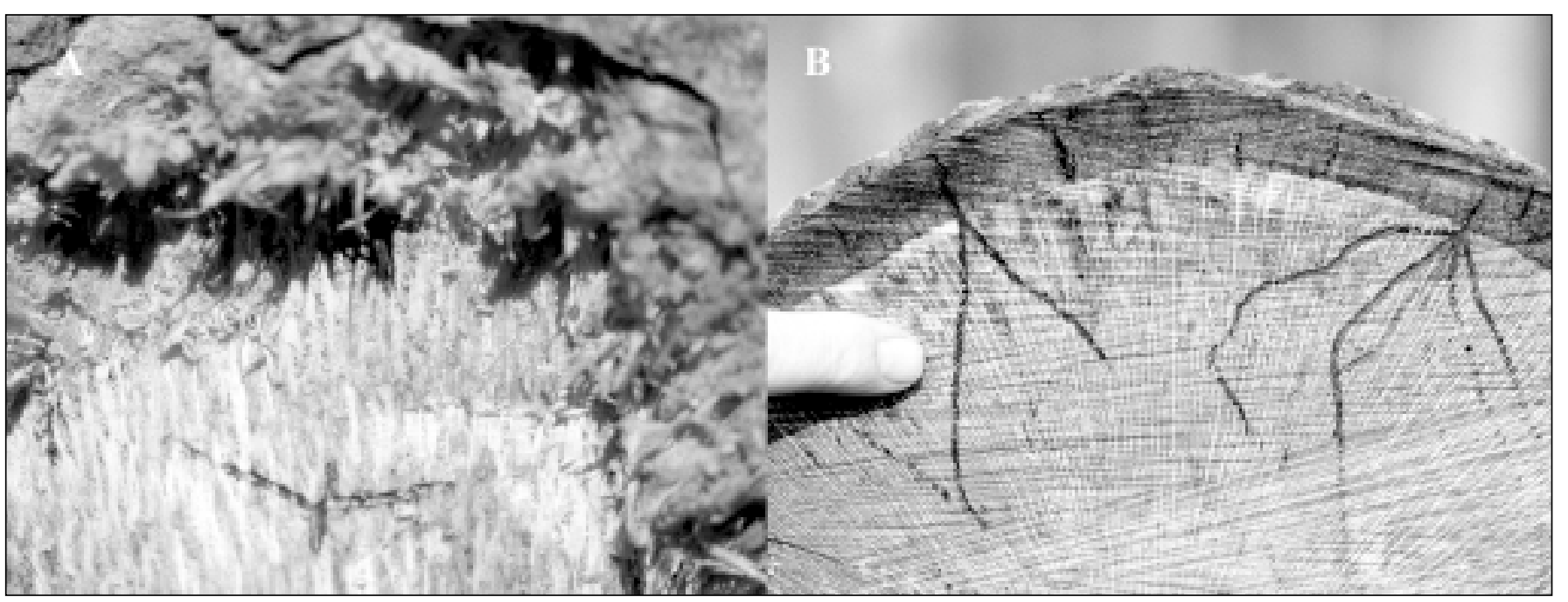

Figure 2. Egg gallery of the western oak bark beetle at the initial stage of construction that scores phloem-xylem tissues (A) significantly differs from tunnels of the oak ambrosia beetle in the sapwood of coast live oak (B). 
Differences in beetle emergence between insecticidetreated bolt sections and control sections were tested by ANOVA using the SAS ${ }^{\circledR}$ GLM (PC SAS, Version 6.03, Cary, NC) procedure.

\section{RESULTS AND DISCUSSION}

Mean cumulative emergence of oak bark beetles and oak ambrosia beetles from permethrin-treated and control bolts is shown in Figure 3. The beetles started to emerge on July 8, 2000 (23 days after the experiment was established). Permethrin significantly prevented emergence of both $P$. pubipennis and M. scutellare $(P=0.001)$. From July 8 to December 9, 2000 ( $\mathrm{n}=155)$, only $98(\mathrm{x}=0.6 \pm 1.5)$ P. pubipennis and 33 $(\mathrm{x}=0.2 \pm 0.3)$ M. scutellare emerged from insecticide-treated bolts, while during the same time period we collected 10,105 $(x=65.2 \pm 49.1) P$. pubipennis and 3,703 $(\mathrm{x}=23.9 \pm$ 18.6) M. scutellare from corresponding untreated (control) bolts. Another difference between treated and control bolts was that beetles emerging from insecticide-treated bolts and recovered dead from the jars had their wing cases (elytra) lifted and wings spread, whereas the few recovered dead from control logs died without opened wing cases (Figure 4).

Interpretation of the data presented here suggests that permethrin application to the bark of infested coast live oaks or California black oaks has the potential to prevent emergence of both western oak bark beetles and oak ambrosia beetles. An unusually long persistence of permethrin on both oak ambrosia beetle and oak bark beetle activity beneath coast live oak bark is demonstrated by the set of pictures in Figure 5. On September 17, three months after a bolt cut $1 \mathrm{~m}$ (3.3 ft) above the ground had been treated, there was no frass, no exit holes on the bark surface, and only slight traces of frass on the bottom of rearing can (T1). The corresponding untreated half log showed abundant produc- tion of frass and tiny exit holes bored by P. pubipennis on the bark surface, as well as rich deposits of frass on the walls and bottom of rearing can $(\mathrm{Cl})$. Both species failed to complete development in the permethrin-treated logs, but the way in which this chemical prevented their emergence is not clear. The effect of permethrin on the emergence of parasites and predators from treated versus untreated bolts could not be evaluated in this experimental design. Further tests are needed to demonstrate whether application of permethrin reduces the hazard of stem breakage.

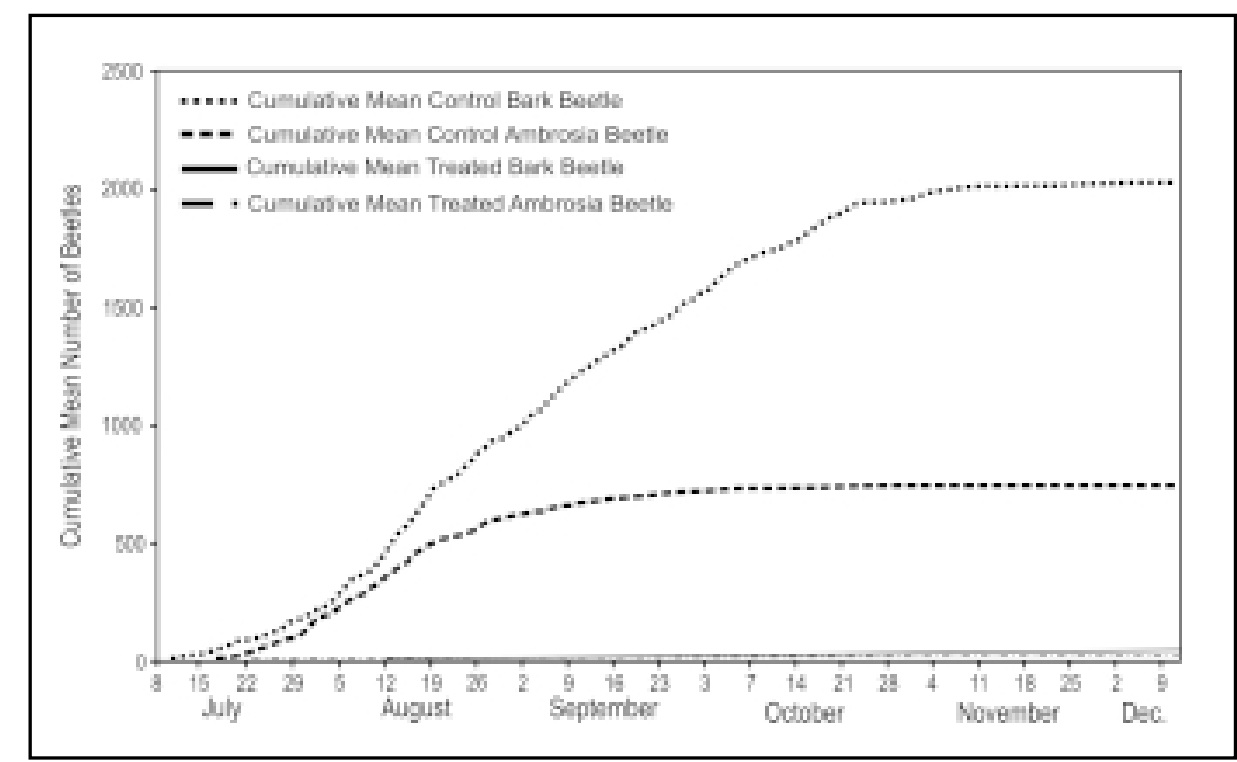

Figure 3. Mean cumulative emergence of bark and ambrosia beetles from permethrintreated and control bolts.

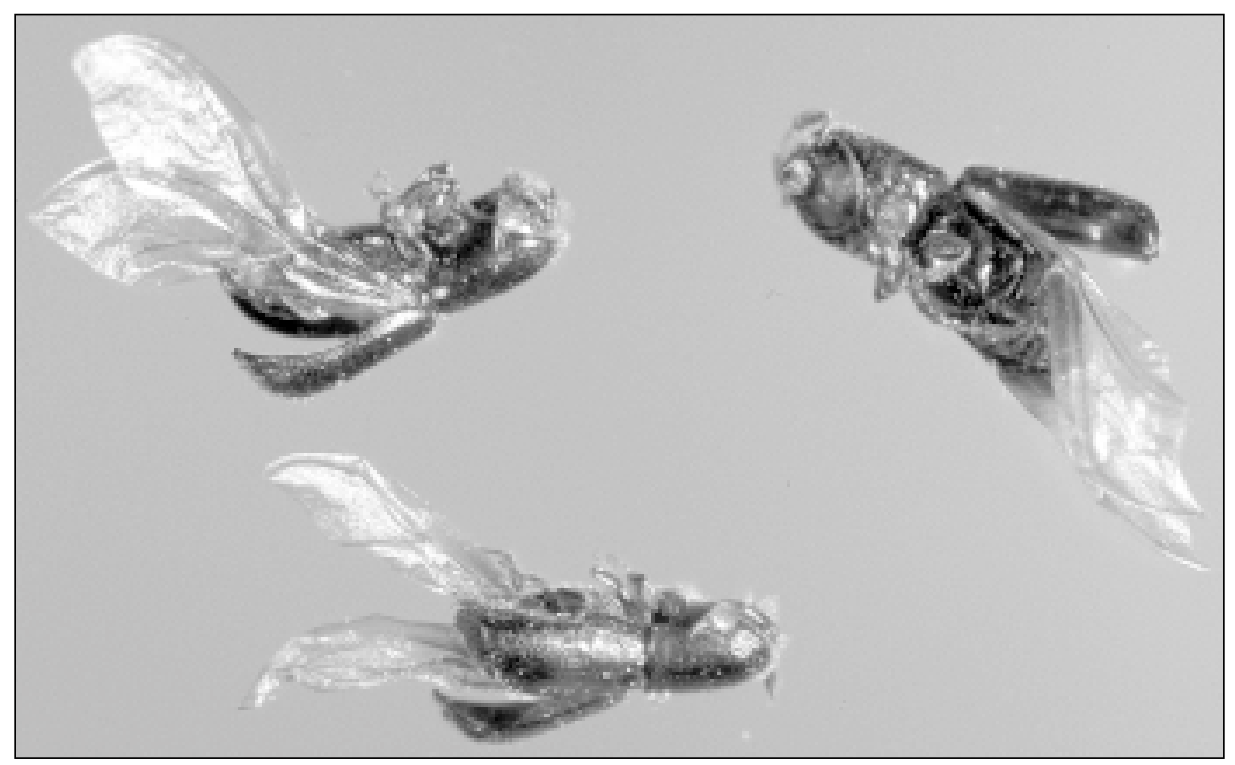

Figure 4. Dead oak ambrosia beetles found in collecting jar after they emerged from permethrin-treated bolts. 


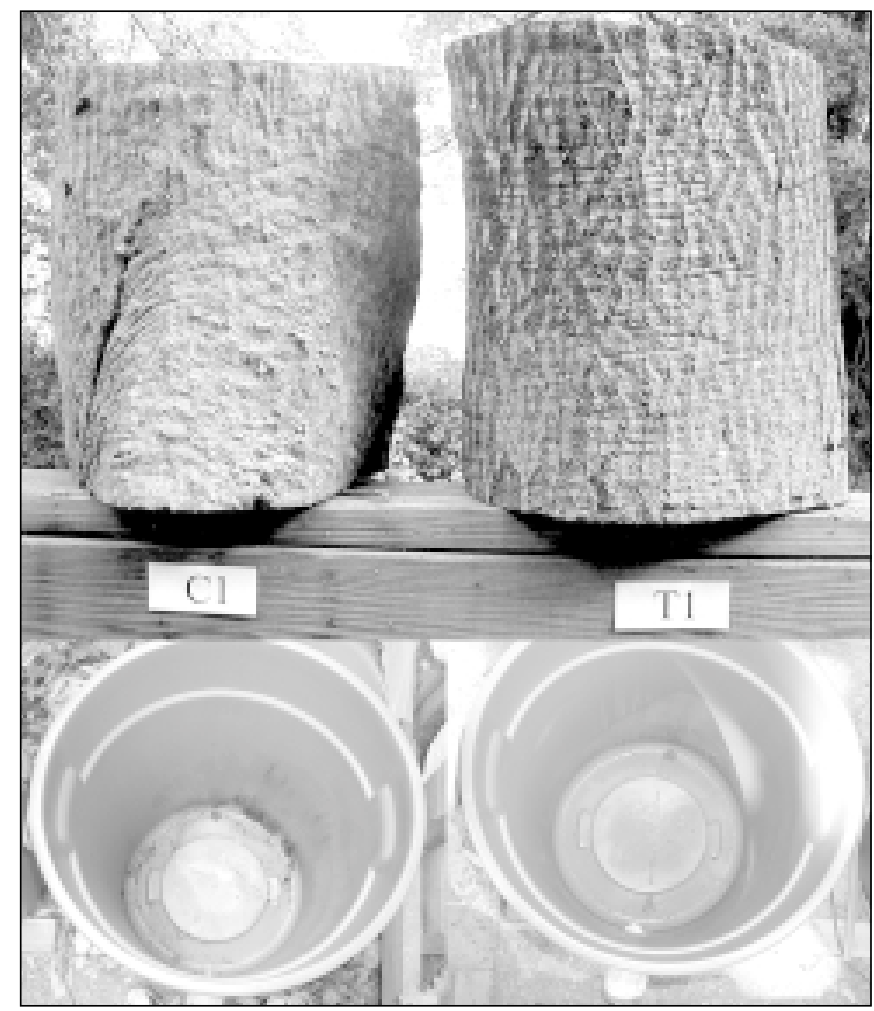

Figure 5. Visual demonstration of permethrin treatment on both oak ambrosia beetle and western oak bark beetle activity beneath the coast live oak bark [a bolt cut $1 \mathrm{~m}$ (3.3 ft) above the ground]. $\mathrm{Cl}$ : untreated half that shows abundant production of frass on the bark surface and in the rearing can. T1: permethrin-treated corresponding half where beetle activity was significantly reduced.

\section{LITERATURE CITED}

Brady, U.E., C.W. Berisford, T.L. Hall, and J.S. Hamilton. 1980. Efficacy and persistence of chlorpyrifos, chlorpyrifos-methyl, and lindane for preventive and remedial control of the southern pine beetle. J. Econ. Entomol. 73:639-641.

Bright, D.E., and R.W. Stark. 1973. The Bark and Ambrosia Beetles of California: Scolytidae and Platypodidae. Bull. Calif. Insect Surv., Vol. 16. University of California Press. $169 \mathrm{pp}$.

Furniss, R.L., and V.M. Carolin. 1978. Western Forest Insects. USDA Forest Service. Misc. Publ. USDA No. 1339. 654 pp.

Garbelotto, M., P. Švihra, and D.M. Rizzo. 2001. Sudden oak death syndrome fells 3 oak species. Calif. Agric. 10(1):10-15.

Hall, R.W., P.J. Shae, and M.I. Haverty. 1982. Effectiveness of carbaryl and chlorpyriphos for protecting ponderosa pine trees from attack by western pine beetle (Coleoptera: Scolytidae). J. Econ. Entomol. 75:504-508.
Rizzo, D.M., M. Garbelotto, J.M. Davidson, G.W. Slaughter, and S.T. Koike. 2002. Phytophthora ramorum as the cause of extensive mortality of Quercus spp. and Lithocarpus densiflorus in California. Plant Dis. 86:205-214.

Speight, M.R. 1981. Beech scale (Cryptococcus fagisuga Lind) and ambrosia beetle (Xyloterus domesticum (L)). Arboric. J. 5:143-146.

Švihra, P. 2000. Protection of Live Oaks Against Attacks by Oak Bark Beetles And Ambrosia Beetles. University of California Cooperative Extension. Pest Alert 3B. 4 pp.

Acknowledgments. This study was funded in part by grants from Cagwin and Darward, Novato, and Dr. and Mrs. Sherman Shapiro. Thanks also to Dr. Andrew J. Storer and Journal of Arboriculture reviewers for critical comments to improve the manuscript.

\author{
${ }^{1 *}$ Horticulture Advisor \\ ${ }^{2}$ Graduate Student \\ ${ }^{3}$ Arboricultural Consultant \\ University of California Cooperative Extension \\ 1682 Novato Blvd., Suite 150B \\ Novato, CA 94947, U.S.
}

${ }^{*}$ Corresponding author. 
Résumé. Des billots ont été coupés de chacun des huit Quercus agrifolia et d'un Q. kelloggii infestés par des insectes perceurs des espèces suivantes: Monothrum scutellare et Pseudopityphthorus pubipennis. Pour chacun des arbres, un billot a été recueilli à $1 \mathrm{~m}$ au-dessus du sol, un second immédiatement sous la fourche d'une branche principale, et un troisième à partir d'une branche de $8 \mathrm{~cm}$ de diamètre. Le permethrin a permis de diminuer significativement l'émergence des deux insectes perceurs sur les deux espèces de chênes, et ce dans le cas des billots traités avec l'insecticide ( $\mathrm{p}=0,001)$ comparativement aux billots-témoins non traités. Ce résultat indique que l'application de permethrin peut permettre de diminuer la densité en insectes perceurs de ces deux espèces dans les forêts urbaines.

Zusammenfassung. Aus einer Q. kelloggii und acht Q. agrifolia, die von Ambrosia-Käfern befallen waren, wurden Stammteile entnommen. Für jeden Baum wurde ein Stammteil in ca. $1 \mathrm{~m}$ Höhe über dem Boden entnommen, ein zweites kurz unter der infizierten Stelle und ein drittes von einem Aststück mit $8 \mathrm{~cm}$ Durchmesser. Permethrin reduziert deutlich das Vorkommen von Ambrosia-Käfern und Eichenrindenkäfern in den insektizidbehandelten Stammteilen ( $P=0.0001)$ im Vergleich zu den Kontrollstücken. Das Ergebnis zeigt, dass der Einsatz von Permethrin die Dichte und das Vorkommen von Besagten Käfern reduzieren kann.

Resumen. Se cortaron trozas de ocho encinos costeros Quercus agrifolia, y una de encino negro de California 2. kelloggii, infestados con escarabajos descortezadores. Para cada árbol, se colectó una troza de 1 metro arriba del suelo, una segunda inmediatamente debajo de la horcadura de la rama principal, y una tercera de un diámetro de $8 \mathrm{~cm}$.

Permethrin redujo significativamente la emergencia de los escarabajos, Monothrum scutellare y Pseudopityphthorus pubipennis, de las trozas tratadas con el insecticida $(\mathrm{P}=$ 0.001) comparados con los de control. Este resultado indica que la aplicación de permethrin a la corteza puede bajar la densidad de los descortezadores en bosques urbanos. 